\title{
Pengaruh brisk walking (jalan cepat) terhadap fungsi hati pada obesitas sentral
}

\author{
${ }^{1}$ Heri Nuryanto \\ ${ }^{2}$ Frans E. Wantania \\ ${ }^{2}$ Bradley J. Waleleng
}

\author{
${ }^{1}$ Kandidat Skripsi Fakultas Kedokteran Universitas Sam Ratulangi \\ ${ }^{2}$ Bagian Ilmu Penyakit Dalam Fakultas Kedokteran Universitas Sam Ratulangi \\ RSUP Prof. Dr. R. D. Kandou Manado \\ Email: herinuryanto126@gmail.com
}

\begin{abstract}
Central obesity is considered as a risk factor that strongly associated with several chronic diseases. Men with waist circumference $\geq 90 \mathrm{~cm}$ and women with waist circumference $\geq 80 \mathrm{~cm}$ are stated as central obesity. This study aimed to determine the effect of brisk walking on liver function in central obesity. This was an experimental field study with a nonrandomized pre-post one group test and control group. This study used consecutive sampling method. There were 30 samples divided into two groups; 15 samples were given intervention and 15 samples as the control group. Data were analyzed with Wilcoxon signed ranks test. The results showed that brisk walking for 1 month decreased the SGPT and SGOT levels, however, statistically there was no significant difference before and after intervention with a $\mathrm{p}$ value $>0.05$. Conclusion: There was no significant influence of brisk walking on liver function in central obesity.
\end{abstract}

Keywords: central obesity, liver function, brisk walking

\begin{abstract}
Abstrak: Obesitas sentral dianggap sebagai faktor risiko yang berkaitan erat dengan beberapa penyakit kronis. Laki-laki dengan lingkar pinggang $\geq 90 \mathrm{~cm}$ atau perempuan dengan lingkar pinggang $\geq 80 \mathrm{~cm}$ dinyatakan sebagai obesitas sentral. Penelitian ini bertujuan untuk mengetahui pengaruh brisk walking (jalan cepat) terhadap fungsi hati pada obesitas sentral. Metode penelitian ini yaitu eksperimental lapangan dengan rancangan non - randomized prepost test with control. Sampel ditentukan dengan teknik pengambilan sampel konsekutif sampling. Terdapat 30 sampel yang dibagi menjadi 2 kelompok yakni 15 sampel yang diberi perlakuan dan 15 sampel sebagai kontrol. Data dianalisis dengan SPSS 20 dan uji Wilcoxon Signed Ranks Test. Hasil penelitian memperlihatkan terjadi penurunan kadar enzim hati SGPT dan SGOT pada sampel yang melakukan brisk walking selama 1 bulan tetapi secara statistik tidak ada perbedaan bermakna sebelum dan sesudah mendapatkan perlakuan dengan nilai p > 0,05. Simpulan: Tidak terdapat pengaruh bermakna dari brisk walking (jalan cepat) terhadap fungsi hati pada obesitas sentral.
\end{abstract}

Kata kunci: obesitas sentral, fungsi hati, brisk walking

Brisk walking merupakan salah satu aktivitas fisik yaitu berjalan cepat daripada kecepatan anda berjalan normal dengan waktu yang ditentukan serta dalam jarak tertentu. ${ }^{1}$ Brisk walking adalah olahraga terbaik dan dianjurkan untuk umur 40 tahun atau lebih, karena Brisk walking
(Jalan Cepat)tidak berat dilakukan untuk usia tersebut dibandingkan dengan olahraga lari. $^{2}$ Porsi brisk walking yang disarankan sekitar 40-50 menit, namun jika belum mampu mencapai waktu tersebut bisa dilakukan secara bertahap. Caranya jalan cepat selama 15 menit, karena umumnya 
setelah 15 menit tersebut denyut nadi aerobik baru tercapai dan dilakukan setiap hari dengan jeda istirahat pada hari ke 7 atau minimal 3 kali perminggu. ${ }^{2}$

Menurut berbagai peneliti, obesitas sentral dapat diartikan sebagai suatu kondisi kronis yang ditandai oleh kelebihan lemak tubuh disertai penumpukkan lemak viseral di perut. Dengan demikian, kelebihan lemak di perut digunakan sebagai komponen kunci dalam penilaian obesitas sentral. ${ }^{3}$ WHO menganjurkan menggunakan lingkar pinggang untuk menentukan obesitas sentral. Dikatakan obesitas sentral apabila lingkar perut $\geq 90 \mathrm{~cm}$ pada pria dan $\geq 80 \mathrm{~cm}$ pada wanita. $^{4,5}$ Sebaiknya diukur pada pertengahan antara batas bawah iga dan krista iliaka, dengan menggunakan ukuran pita secara horizontal pada saat akhir ekspirasi dengan kedua tungkai dilebarkan 20-30 cm. ${ }^{5}$ Prevalensi obesitas sentral tahun 2013 dengan penduduk yang berumur $\geq 15$ tahun secara nasional adalah 26,6\%, lebih tinggi dari pada tahun 2007 $(18,8 \%)$. Prevalensi obesitas terendah di Nusa Tenggara Timur (15,2 \%) dan tertinggi di DKI Jakarta (39,7 \%). Sebanyak 18 Provinsi memiliki prevalensi obesitas sentral di atas angka nasional yakni salah satunya Provinsi Sulawesi Utara $(36,0 \%)^{6}$

\section{Hubungan Obesitas dengan Perlemakan Hati}

Perlemakan hati adalah hati yang terinfiltrasi oleh lemak, biasanya akibat penyalahgunaan alkohol, pembedahan bypass jejunoileal, atau akibat kadar diabetes mellitus; lemak terbentuk seperti droplet besar dan hepar membesar tetapi dengan konsistensi yang normal dan sering bersifat asimpomatik. ${ }^{3}$ Adiponektin berperan meningkatkan oksidasi asam lemak di otot, meningkatkan kerja insulin di hati dan menurunkan akumulasi lipid pada makrofag. ${ }^{7}$ Pada obesitas terjadi penurunan kadar adiponektin yang akan menyebabkan penurunan daya proteksi hati terhadap lemak sehingga terjadi resistensi insulin.?

Peningkatan massa lemak di jaringan adiposa terutama pada keadaan obesitas sentral menyebabkan pelepasan asam lemak bebas (Free Fatty Acid / FFA). Selain itu jaringan adiposa juga mengeluarkan TNF- $\alpha$ sehingga mengakibatkan resistensi insulin yang akhirnya akan meningkatkan lipolisis. Obesitas sentral atau abdominal sangat berkaitan erat dengan penyakit perlemakan hati. Resistensi insulin merupakan mekanisme kunci dalam patogenesis penyakit perlemakan hati. Resistensi insulin menyebabkan akumulasi lemak di hepatosit melalui dua mekanisme utama yaitu lipolisis dan hiperinsulinemia. ${ }^{8}$

\section{Hubungan Perlemakan Hati dengan Profil Enzim Hati}

Kadar AST/SGOT dan ALT/SGPT serum meningkat pada beberapa keadaan, hampir semua penyakit hati. Secara keseluruhan aktivitas ALT lebih spesifik untuk mendeteksi penyakit hati pada pasien asimptomatik seperti pada perlemakan hati. Peningkatan konsentrasi ALT dianggap sebagai akibat kerusakan hepatosit pada perlemakan hati. Chang dkk pada penelitiannya terhadap 5237 partisipan laki-laki Korea yang nampak sehat menemukan peningkatan konsentrasi ALT bahkan dalam interval rujukan merupakan prediktor bebas dari insiden perlemakan hati. ${ }^{9}$

\section{Hubungan Exercise (Brisk walking) dengan Penurunan Perlemakan Hati}

Aktivitas fisik yakni Brisk walking adalah kegiatan berjalan cepat yang dapat dilakukan oleh semua umur.Brisk walking sangat bermanfaat untuk kesehatan tubuh salah satunya untuk penderita obesitas sentral atau abdominal. ${ }^{10}$ Aktivitas fisik dapat meningkatkan sensitivitas insulin. Salah satu contoh dari mekanisme ini adalah Nitric Oxide (NO). Beberapa penelitian menunjukkan bahwa NO ikut serta dalam mengatur transport glukosa yang diperantarai oleh kontraksi. Produksi NO meningkat drastis pada otot rangka yang berkontraksi oleh karena stimulasi oleh Nitric Oxide Synthase (NOS). 
Peningkatan NO berakibat pada peningkatan aliran darah ke otot. ${ }^{11}$ Aktivitas fisik (brisk walking) merupakan olahraga aerobik yang dapat menurunkan faktor resiko obesitas sentral seperti perlemakan hati. Selain untuk menjaga kebugaran, olahraga juga dapat menurunkan berat badan dan memperbaiki sensitifitas insulin. Efek ini terutama terjadi sensitifitas insulin pada otot. ${ }^{12}$

\section{METODE PENELITIAN}

Jenis penelitian ini eksperimental lapangan dengan rancangan non randomized pre-post test with control. Untuk brisk walking (jalan cepat) bertempat di Bagian Ilmu Penyakit Dalam RSUP Prof. Dr. R.D Kandou sedangkan untuk pemeriksaan fungsi hati (SGOT dan SGPT) dilaksanakan di Laboratorium ProKita Penelitian ini dilakukan pada bulan
November - Desember 2015.

Sampel penelitian ialah Mahasiswa P3D dan PPDS I di Bagian Penyakit Dalam RSUP Prof. Dr. R. D. Kandou Manado dengan obesitas sentral. Sampel diambil menggunakan teknik konsekutif sampling Sampel berjumlah 30 dan dibagi menjadi 2 kelompok yakni 15 sampel yang diberi perlakuan dan 15 sampel sebagai kontrol. Kelompok perlakuan diberikan perlakuan brisk walking yang dilakukan oleh sampel dua kali dalam seminggu dalam selang waktu 1 bulan dengan durasi 30 menit untuk setiap brisk walking menggunakan treadmill dengan kecepatan 4,5 km/jam

\section{HASIL PENELITIAN}

Penelitian dilakukan di Bagian Penyakit Dalam RSUP Prof. Dr. R. D. Kandou Manado dengan waktu penelitian pada bulan November - Desember 2015

Tabel 1. Karakteristik Responden (Brisk walking) berdasarkan Lingkar perut

\begin{tabular}{ccccc}
\hline $\begin{array}{c}\text { Lingkar } \\
\text { Perut }(\mathrm{cm})\end{array}$ & $\begin{array}{c}\text { Jumlah } \\
(\text { sebelum) }\end{array}$ & $\begin{array}{c}\text { Persentase } \\
(\%)\end{array}$ & $\begin{array}{c}\text { Jumlah } \\
\text { (Sesudah) }\end{array}$ & $\begin{array}{c}\text { Persentase } \\
(\%)\end{array}$ \\
\hline$<90$ & - & - & - & - \\
$90-100$ & 8 & $53 \%$ & 8 & $53 \%$ \\
$>100$ & 7 & $47 \%$ & 7 & $47 \%$ \\
\hline Total & 15 & $100 \%$ & 15 & $100 \%$ \\
\hline
\end{tabular}

Tabel 2. Hasil Uji Wilcoxon Kelompok Perlakuan dan Kontrol Pemeriksaan SGOT dan SGPT Pre test

\begin{tabular}{ccc}
\hline Parameter & $\mathrm{Z}$ & Sig. \\
\hline $\begin{array}{c}\text { SGOT Pre } \\
\text { kontrol-b.w }\end{array}$ & $-1,023$ & 0,306 \\
$\begin{array}{c}\text { SGPT Pre } \\
\text { kontrol-b.w }\end{array}$ & 0,483 & 0,629 \\
\hline
\end{tabular}

Tabel 3. Hasil Uji Wilcoxon Kelompok Perlakuan dan Kontrol Pemeriksaan SGOT dan SGPT Post test

\begin{tabular}{ccc}
\hline Parameter & Z & Sig. \\
\hline SGOT Post & $-0,625$ & 0,532 \\
kontrol-b.w & & \\
$\begin{array}{c}\text { SGPT Post } \\
\text { kontrol-b.w }\end{array}$ & $-0,114$ & 0,910 \\
\hline
\end{tabular}

Tabel 4. Hasil Uji Wilcoxon Kelompok Perlakuan dan Kontrol Pemeriksaan SGOT dan SGPT Post test

\begin{tabular}{ccc}
\hline Parameter & Z & Sig. \\
\hline SGOT Post & $-0,625$ & 0,532 \\
kontrol-b.w & & \\
$\begin{array}{c}\text { SGPT Post } \\
\text { kontrol-b.w }\end{array}$ & $-0,114$ & 0,910 \\
\hline
\end{tabular}

Tabel 5. Hasil Uji Wilcoxon Kelompok Kontrol Pemeriksaan SGOT dan SGPT Sebelum dan Sesudah

\begin{tabular}{ccc}
\hline Parameter & $\mathrm{Z}$ & Sig. \\
\hline SGOT Post & $-0,540$ & 0,589 \\
test-pre test & & \\
$\begin{array}{c}\text { SGPT Post test- } \\
\text { pre test }\end{array}$ & $-1,279$ & 0,201 \\
\hline
\end{tabular}


Tabel 6. Uji Hasil Uji T Berpasangan (Lingkar Perut) Kelompok Perlakuan

\begin{tabular}{ccc}
\hline Parameter & IK & Sig. \\
\hline Lingkar perut & $-0,712-$ & 0,001 \\
pre-post test & 2,088 & \\
\hline
\end{tabular}

\section{Kelompok Perlakuan}

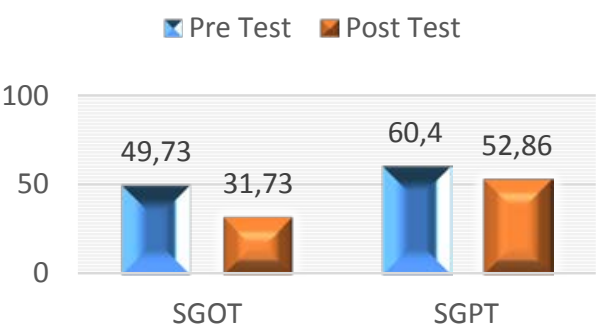

Gambar 1. Diagram hasil perbandingan prepost test kelompok perlakuan

\section{BAHASAN}

Dalam Penelitian ini, data di peroleh dari aktivitas melakukan brisk walking dan pemeriksaan SGOT dan SGPT yang dilakukan di Laboratorium Pro Kita. Sebelum melakukan brisk walking sampel penelitian sudah terlebih dahulu melakukan pemeriksaan SGOT dan SGPT kemudian setelah melakukan brisk walking selama 1 bulan di lakukan pemeriksaan kembali. Dalam penelitian ini seluruh sampel perlakuan termasuk dalam kategori obesitas sentral. Ada 8 sampel yang memiliki lingkar perut 90 sampai $100 \mathrm{~cm}$ dan 7 sampel memiliki lingkar perut lebih dari $100 \mathrm{~cm}$. Aktivitas fisik aerobik dalam hal ini brisk walking mampu menurunkan ukuran lingkar perut karena berkaitan erat dengan penurunan persentase lemak tubuh terutama lemak viseral. ${ }^{13}$ Pada penelitian ini terdapat 10 sampel penelitian dari 15 sampel yang mengalami penurunan lingkar perut.

Penelitian ini di uji kebenaran hipotesis menggunakan program Statictical Product and Service Solutions (SPSS) dengan menguji normalitas data menggunakan uji Shapiro-Wilk dan didapatkan hasil signifikansi untuk kelompok perlakuan kurang dari 0,05 di semua variabel menunjukkan sebaran data yang tidak normal. Pada distribusi data yang tidak normal maka untuk menguji hipotesis komparatif dua kelompok berpasangan digunakan uji Wilcoxon.

Hasil uji Wilcoxon pada kelompok perlakuan SGOT sebelum dan sesudah brisk walking yakni nilai signifikansi yang didapat lebih besar dari nilai ketetapan signifikansi yang ditentukan 0,271 $(>0,05)$. Begitupun dengan hasil uji Wilcoxon pada kelompok perlakuan SGPT sebelum dan sesudah brisk walking yakni nilai signifikansi yang didapat lebih besar dari nilai ketetapan signifikansi yang ditentukan $0,733(>0,05)$. Maka dari hasil tersebut menyatakan tidak ada perbedaan bermakna antara hasil pemeriksaan SGOT dan SGPT sebelum dan sesudah melakukan brisk walking selama 1 bulan. Hasil uji Wilcoxon pada kelompok kontrol yakni sama dengan kelompok perlakuan artinya tidak terdapat tidak ada perbedaan bermakna antara hasil pemeriksaan SGOT dan SGPT sebelum dan sesudah.

Uji Wilcoxon pada kelompok perlakuan dan kontrol pre test mendapatkan signifikansi 0,306 (>0,05) pada uji Wilcoxon yang menyatakan bahwa tidak terdapat perbedaan SGOT antara Pre test kelompok Perlakuan dan Kontrol dan didapatkan signifikansi 0,629 $(>0,05)$ pada uji Wilcoxon yang menyatakan bahwa tidak terdapat perbedaan SGPT yang bermakna antara pre test kelompok perlakuan dan kontrol.

Pada post test kelompok perlakuan dan kontrol didapatkan hasil signifikansi pada pemeriksaan SGOT lebih besar dari nilai ketetapan signifikansi yang ditentukan $0,532(>0,05)$ begitupun dengan nilai signifikansi pada pemeriksaan SGPT yang berarti tidak ada perbedaan bermakna antara Kelompok perlakuan dan kontrol pada Post test SGOT dan SGPT. Pada penelitian ini terdapat beberapa faktor yang menjadi perancu seperti kurangnya kontrol diet, gaya hidup seperti kondisi stress dan depresi.

Uji normalitas data pada kelompok perlakuan berdasarkan pemeriksaan lingkar 
perut didapatkan hasil signifikansi Uji Saphiro-Wilk lebih dari 0,05 yang berarti data berdistribusi normal, maka dilakukan uji dengan menggunakan uji t berpasangan. Hasil dari uji tersebut didapatkan nilai signifikansi lebih kecil dari nilai ketetapan signifikansi $\quad 0,001 \quad(<0,05) \quad$ yang menyatakan bahwa terdapat perbedaan bermakna pada lingkar perut setelah sebulan dilakukan brisk walking.

Berdasarkan hasil penelitian Tiala ${ }^{14}$ tidak terdapat perbedaan bermakna antara aktifitas fisik dengan obesitas sentral pada siswa obesitas sentral. Dalam penelitian tersebut juga menjelaskan penyebab tidak terdapatnya hubungan yang signifikan antara aktivitas fisik dengan lingkar pinggang pada siswa obes sentral yakni dapat disebabkan karena beberapa faktor. Beberapa faktor yaitu asupan gizi, besar keluarga, gaya hidup yaitu kebiasaan merokok, kondisi stress dan depresi. Maka dari itu aktivitas fisik dalam penelitian tersebut tidak terdapat perbedaan yang bermakna.

Hasil perhitungan pemeriksaan SGOT dan SGPT kelompok perlakuan nilai ratarata SGOT sebelum 49,73 turun menjadi 31,73 dengan selisih 18 (36,2\%) begitupun nilai rata-rata SGPT sebelum 60,4 turun menjadi 52,86 dengan selisih 8 (13,2\%). Hasil pemeriksaan tersebut terdapat selisih, yang berarti sebagian mengalami penurunan enzim hati setelah melakukan brisk walking. Keating et al mendapatkan terjadi penurunan perlemakan hati setelah melakukan latihan aerobik tanpa penurunan berat badan yang bermakna secara klinis. ${ }^{15}$

\section{SIMPULAN}

Berdasarkan hasil penelitian dan bahaasan dapat disimpulkan bahwa terjadi penurunan kadar enzim hati SGPT dan SGOT pada yang melakukan brisk walking selama 1 bulan tetapi secara statistik tidak ada perbedaan bermakna sebelum dan sesudah mendapatkan perlakuan.

\section{SARAN}

$\begin{array}{ccc}\text { Disarankan } & \text { untuk } & \text { penelitian } \\ \text { selanjutnya dapat } & \text { diberik } & \text { perlakuan }\end{array}$

berbagai aktifitas fisik dengan umur dan jenis kelamin yang lebih bervariasi.

\section{DAFTAR PUSTAKA}

1. Admin. 2014. Manfaat Brisk Walking. Wordpress. Available from: www.Indotopinfo.com/manfaat-daribrisk-walking.htm. 03 oktober 2015

2. Mangkoko. 2014. Brisk Walking. [cited 3 oktober 2015]. Available from: www.mangkoko.com.

3. Pujiati S. Prevalensi dan Faktor Risiko Obesitas Sentral pada Penduduk Dewasa Kota dan Kabupaten Indonesia Tahun 2007. Depok: Universitas Indonesia; 2010.

4. Hirlan. Obesitas. In: Rani A, Simadibrata MK, editors. Buku Ajar Gastroenterologi. Jakarta: InternaPublishing, 2011.

5. Syam AFM. Malnutrisi. In: Sudoyo AW, et al, editors. Buku Ajar Ilmu Penyakit Dalam. Jakarta: Interna Publising, 2011; p. 225-31.

6. RISKESDAS. 2013. Prevalensi Obesitas Sentral Umur $\geq 15$ tahun. Badan Penelitian dan Pengembangan Kesehatan Kementrian Kesehatan RI

7. Darmono. Obesitas dan lipid: Aspek global terhadap sindroma metabolik. In: Tony S, Tjokorda GDP, editors. Perpektif baru dalam endokrinologi dasar \& klinik. Semarang: Balai Penerbit Universitas Diponegoro, 2007; p. 1-9.

8. Levine JE, Schwimmer JB. NAFLD/NASH in Children. In: Geoffrey CF, Jacob PD, Arthur JM, editors. Fatty liver disease NASH and related disorders. Blackwell Publishing, 2005: p. 229-40.

9. Riskesdas. Pedoman Pengukuran dan Pemeriksaan. Jakarta 2007 Avaiable from: URL: http://www.riskesdas. litbang.depkes.go.Id/download/ PedomanPengukuran.pdf

10.Agadoni L. 2014. Brisk Walking. [cited 5 Oktober 2015]. Available from: http://www.livestrong.com/article/46 7323-what-is-the-meaning-of-briskwalking.

11.Romadhona S. Hubungan Kadar Adiponektin dengan Penyakit Perlemakan Hati Non Alkoholik pada Remaja Obesitas. Semarang: 
Universitas Diponegoro; 2009.

12.Sazli IB. Efek Latihan dalam Memperbaiki Sensitifitas Insulin. Reading Assigment Divisi Endokrinologi Departemen Penyakit Dalam FK.USU-RSUP HAM. 2008.

13.Candrawati S. Hubungan tingkat aktivitas fisik dengan indeks massa tubuh (IMT) dan lingkar pinggang mahasiswa. The Soedirman Journal of Nursing. 2011;6:112-8.

14.Tiala MEARP, Tanudjaja GN, Kalangi
SJR. Hubungan Antara Aktifitas Fisik dengan Lingkar Pinggang pada Siswa Obesitas Sentral. Universitas Sam Ratulangi Manado. eBm. 2013;1(1):455-60.

15.Keating SE, Hackett DA, Parker HM, O'Connor HT, Gerofi JA, Sainsbury A, et al. Effect of aerobic exercise training dose on liver fat and visceral adiposity. J Hepat. 2015;63(1):174-82. 